\title{
Pengembangan Bahan Ajar Berorientasi Environmental Sustainability Education Berbasis Literasi Sains Dan Realitas Lokal Sumatera Selatan
}

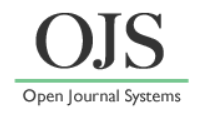

\author{
Nike Anggraini $^{1 *}$, Khoiron Nazip ${ }^{2}$, Dian Sri Andriani ${ }^{3}$ \\ ${ }^{1}$ Program Studi Pendidikan Biologi Jurusan PMIPA, FKIP Universitas Sriwijaya, Palembang, Sumatera Selatan \\ ${ }^{2}$ Program Studi Pendidikan Biologi Jurusan PMIPA, FKIP Universitas Sriwijaya, Palembang, Sumatera Selatan \\ ${ }^{3}$ Program Studi PLS Jurusan Pendidikan, FKIP Universitas Sriwijaya, Palembang, Sumatera Selatan \\ *Email: anggraini.nike@pps.unsri.ac.id
}

DOI: https://doi.org/10.33369/pendipa.5.3.309-315

\begin{abstract}
This research is aimed to develop teaching materials oriented to environmental sustainability education based on science literacy and the reality of South Sumatera. The subject in this study was biology education students who were teaching Human and Environmental Sciences courses. This study used a Research \& Development from Borg and Gall with four stages design: preliminary study, planning, development, validation and revision. The limited trial was carried out to some of the students of the Palembang class (15 students) and was carried out on a total of 75 students of the total students in the Palembang and Indralaya class. The teaching materials used were developed according to North American Asociation For Environmental Education (NAEE) with 6 key characteristics of teaching materials with an orientation of Environmental Sustainability Education, which include: fairness \& accuracy, depth, emphasis on skill building, action orientation, instructional soundness and usability. The technique of collecting data was through observation, documentation, questionnaires and tests. The legibility test used the Cloze test and validation test by material experts and technology experts. Based on the results of validation by material experts, it was found that $82.4 \%, 78.4 \%$ were by validation of technology experts, which means that the teaching materials developed, were in the good category. Based on the legibility test, environmental teaching materials high legibility.
\end{abstract}

Keywords: Environmental Sustainability Education, Based on local, Science Literacy.

Penelitian ini merupakan penelitian pengembangan bahan ajar berorientasi environmental sustainability education berbasis literasi sains dan realitas Sumatera Selatan. Subjek dalam penelitian ini adalah mahasiswa Pendidikan Biologi FKIP Unsri yang mengikuti Mata Kuliah Manusia dan Ilmu Lingkungan. Penelitian ini menggunakan desain penelitian Research \& Development (R\&D) dari Borg dan gall dengan empat tahapan yakni studi pendahuluan, perencanaan, pengembangan, validasi dan revisi. Uji coba terbatas dilakukan pada sebagian mahasiswa kelas palembang yang berjumlah 15 orang dan uji coba skala luas dilakukan pada keseluruhan mahasiswa berjumlah 75 dari keseluruhan mahasiswa di kelas palembang dan indralaya. Bahan ajar yang digunakan dikembangkan menurut National Asociation For Environmental Education (NAEE) dengan 6 karateristik kunci bahan ajar berorietasi Environmental Sustainability Education yang meliputi : fairness \& accuracy, depth, emphasis on skill building, action orientation, instructional soundness dan usability. Teknik Pengumpulan data dilakukan melalui observasi, dokumentasi, angket dan tes. Uji keterbacaan menggunakan Cloze test dan sebelumnya dilakukan tes validasi oleh ahli materi, dan ahli teknologi. Berdasarkan hasil validasi oleh ahli materi didapat bahwa 82,4\% , dan validasi ahli teknologi sebesar 78,4 \% yang artinya bahan ajar yang dikembangkan dalam kategori baik. Berdasarkan uji keterbacaan, bahan ajar lingkungan memiliki keterbacaan yang tinggi.

Kata Kunci: Environmental Sustainability Education, Realitas lokal, Literasi sains. 


\section{PENDAHULUAN}

Istilah Sustainability education pertama kali tercetus pada laporan World Commission on Environment and Development atau yang dikenal dengan laporan Brundtland pada tahun 1987. Konsep sustainability sangat berkaitan erat dengan istilah lingkungan, ekonomi dan sosial untuk generasi di masa depan. Para ahli juga mengemukakan bahwa dalam bidang bisnis, pengembangan berkelanjutan (sustainable development) juga terikat pada tujuan yang berkaitan dengan keadilan sosial, efisiensi dalam ekonomi dan lingkungan, sebagaimana paparan berikut "Business sustainability entails the adoption of objectives for sustainable development, namely social equity, economic efficiency, and environmental performance". Dari konsep tersebut, terdapat dua fokus utama yang menjadi dasar pemikiran penting dalam hal ini yakni pengembangan dan lingkungan. Kedua hal ini tentu sangat erat dalam kehidupan manusia sehari-hari. Dimulai dari pendidikan. Pendidikan lingkungan yang berkelanjutan dapat diajarkan dan dirancang konsep pedagoginya untuk menanmkan karakter sikap peduli lingkungan sedari dini (Steg \& Abrahamse, 2005).

Sumatera selatan merupakan slah satu provinsi di Indonesia yang terletak di bagian selatan Pulau Sumatera. Secara astronomi, Sumsel terletak antara 1-4 ${ }^{0}$ Lintang Selatan dan $102-106^{0}$ Bujur Timur dengan luas daerah mencapai $87.017 .41 \mathrm{~km}^{2}$. Dengan kondisi geografis sedemikian rupa, Sumsel disebut juga sebagai kota air karena sebagian besar berupa rawa-rawa dan anak sungai. Seiring meningkatnya jumlah penduduk, Sumsel seolaholah berdiri di atas sungai dengan rumah apung yang identik. Hal ini menyebabkan kondisi lingkungan menjadi semakin memperhatikan, karena banyak penduduk yang melakukan aktivitas disungai. Sungai musi bahkan mengalami pendangkalan sehingga menyebabkan terjadinya banjir dimana-mana dan berdampak bagi spesies ikan belida (Notopterus chitala H.B) yang merupakan ikan khas Palembang hingga menjadi semakin langka (BPS, 2013).
Globalisasi dan perkembangan ilmu pengetahuan, teknologi dan seni (IPTEKS) menuntut manusia untuk melek sains, melek teknologi danpengetahuan. Akan tetapi, jika kemajuan ini tidak diiringi dengan kesadaran dan sikap perduli lingkungan, malah akan memperburuk kondisi lingkungan alam. Hal ini menjadi tantangan yang harus dihadapi oleh pemerintah, akademisi dan stakeholder pendidikan. Melalui pemanfaatan sumber belajar dari lingkungan sekitar dan kehidupan sehari-hari, pembelajaran dapat mengembangkan kreativitas dalam sains, keterampilan proses sains, kemampuan berpikir, bersikap ilmiah, dan mampu menyelesaikan masalah-masalah secara ilmiah (scientific literacy) pada lingkungan sekitar (lokal).

Banyak kajian yang membahas tentang prilaku manusia terhadap lingkungan sekitar. Salah satunya terkenal dengan sebutan manusia mentalis frontier. Yakni sekelompok manusia yang memiliki pikiran bahwa mereka bukanlah bagian dari lingkungan Kelompok ini beranggapan bahwa sumber daya alam itu tidak terbatas dan tidak akan pernah habis. Penyimpangan prilaku seperti ini yang dapat menimbulkan krisis lingkungan (Chiras, 1991)

Literasi sains dapat dibekalkan kepada mahasiswa dengan merangsang mahasiswa memanfaatkan sumber belajar di lingkungan sekitar salah satunya dengan memanfaatkan potensi dan kearifan lokal. Permasalahan lingkungan yang terjadi di sekitar serta berbagai isu budaya lokal yang berkembang dapat dijadikan sarana untuk membelajarkan seorang pembelajar tentang literasi sains.

Penurunan kualitas lingkungan sebenarnya dapat diubah dengan melakukan transformasi pada prilaku lingkungan bermental frontier menjadi perilaku berwawasan lingkungan. Perilaku berwawasan lingkungan mengacu pada perbuatan manusia yang secara sadar mencintai lingkungan dengan dilandasi sikap tanggung jawab (responsibility) (Steg, \& Abrahamse, 2005). 
Pemahaman peserta didik terhadap permasalahan lingkungan akan membuat setiap individu dapat memahami dan menafsirkan kondisi lingkungan sekitar mereka. Sehingga mereka dapat memutuskan tindakan yang tepat dalam mempertahankan, memulihkan serta meningkatkan kondisi lingkungan tersebut (Maguire, 1980). Tujuan utama dalam pendidikan lingkungan yakni membentuk manusia yang memiliki kecakapan literasi lingkungan yang baik, peduli terhadap masalah lingkungan dan dapat mengambil tindakan untuk menjaga lingkungan (Sriyati, 2015).

Pemerintah menanggapi persoalan tentang lingkungan hidup dengan sangat serius dengan berkomitmen untuk menjaga lingkungan dan kerusakan lingkungan melalui Pendidikan. Melalui pendidikan, pemerintah berharap akan muncul suatu sikap peduli lingkungan yang akan memunculkan tahap-tahap kepedulian lingkungan dalam diri peserta didik sedari dini. Pendidikan lingkungan kemudian mulai di terapkan di dalam kurikulum yang terintegrasi dalam kurikulum 1984 sebagai Pendidikan Lingkungan Hidup (PLH) yang disisipkan dalam semua mata pelajaran. Baru kemudian pada kurikulum 2006 (KTSP), pendidikan lingkungan hidup mulai diberi peluang untuk menjadi mata pelajaran sendiri. Pendidikan Lingkungan merupakan suatu proses pengenalan nilai dan konsep untuk membangun sebuah pengetahuan, keterampilan dan sikap untuk memahami hubugan antar budaya dan lingkungan bio-fisik (Segara, 2015). Melalui Kementerian Pendidikan dan Kebudayaan Bersama Kementerian Lingkungan Hidup mengembangkan Sekolah Peduli dan Berbudaya Lingkungan (SPBL) yang dikenal dengan program Adiwiyata (Azhar \& Alfitri, 2016). Tujuan utama dalam pendidikan lingkungan yakni membentuk manusia yang memiliki kecakapan literasi lingkungan yang baik, peduli terhadap masalah lingkungan dan dapat mengambil tindakan untuk menjaga lingkungan (Sriyati, 2015).

Hasil penelitian yang dilakukan oleh (AbuHola, 2011; Cunningham, 2008; Sontay, Gökdere, \& Usta, 2015) menyatakan bahwa literasi lingkungan pada peserta didik di sekolah masih sangat rendah. Ada banyak faktor yang menyebabkan hal ini terjadi, salah satunya yakni kurangnya minat untuk mengetahui dan mempelajari masalah-masalah lingkungan. Sebagai tiang utama dalam pendidikan, sudah tentu bahwa guru menjadi contoh pertama yang ditiru oleh para peserta didik. Sehingga, sebagai seorang guru harus memberikan stimulus dan contoh nyata kepada peserta didik dalam bersikap dan memecahkan permasalahan lingkungan. Sebagai mata pelajaran IPA, secara spesifik Biologi bukan hanya pengetahuan dasar berupa fakta atau konsep-konsep saja, melainkan suatu proses penemuan yang sangat erat kaitannya dengan lingkungan. Oleh karena itu, mengetahui kemampuan awal literasi lingkungan pada calon guru Biologi menjadi emergency untuk dilakukan sebelum mereka terjun kelapangan menjadi Guru yang sebenarnya. Konsep literasi lingkungan dikembangkan dari konsep literasi sains. Sehingga Status literasi lingkungan seseorang dapat diukur berdasarkan kriteria-kriteria literasi lingkungan, yaitu: kompetensi lingkungan, pengetahuan lingkungan dan sikap terhadap lingkungan (NAEE, 2011; PISA, 2016).

Untuk itu realitas lokal yang ada di Sumatera Selatan beserta permasalahanpermasalahan lingkungan yang terjadi sangat perlu untuk diangkat dalam pembelajaran di sekolah, yang salah satu caranya adalah dengan mengintegrasikannya ke dalam bahan ajar berorientasi enviromental sustainability education berbasis literasi sains dan realitas lokal agar mahasiswa lebih memahami kondisi riil yang ada di lingkungannya serta menumbuhkan sikap peduli terhadap lingkungan. Memperbaiki kecakapan literasi lingkungan dimaksudkan untuk mempersiapkan manusia yang memahami dan dapat memecahkan isu isu lingkungan, karena hanya orang-orang yang melek lingkungan sajalah yang dapat menemukan solusi terhadap permasalahan-permasalahan tersebut

\section{METODE PENELITIAN}

\section{- Desain Penelitian}

Desain dalam penelitian ini yakni penelitian pengembangan Research and Development 
$(R \& D)$ yang dikembangkan oleh Borg dan Gall dengan 4 tahapan studi pendahuluan, perencanaan, pengembangan, validasi dan revisi. Uji coba skala kecil dilakukan dengan memilih 15 siswa dari kelas palembang, kemudian dilanjutkan dengan uji coba skala luas pada kelas palembang dan indralaya. Pengembangan bahan ajar dilakukan dengan mengikuti 6 tahapan menurut NAEE yaitu: fairness \& accuracy, depth, emphasis on skill building, action orientation, instructional soundness dan usability

\section{- Subjek Penelitian}

Subjek penelitian adalah mahasiswa Prodi Pendidikan Biologi FKIP Unsri yang berjumlah 75 orang yang terdiri dari kelas palembang dan indralaya Tahun Ajaran 2019/2020. Teknik pengambilan sampel yakni Purposive sampling dengan memilih kelas/mahasiswa yang sedang mengambil mata kuliah Manusia dan Lingkungan di Semester II.

\section{- Instrumen Penelitian}

Pengambilan data dilakukan melalui tahapan observasi, angket, tes dan dokumentasi yang kemudian dianalisis secara kualitatif. Untuk mengetahui kualitas bahan ajar yangdigunakan pada penelitian, dilakukan uji validasi ahli materi, teknologi dan uji keterbacaan. Validasi kelayakan bahan ajar dari aspek materi dan kegrafikaan dilakukan dengan menggunakan angket validasi, sedangkan untuk mengetahui tingkat keterbacaan dilakukan dengan tes keterbacaan uji rumpang (cloze test) (Ozgurler \& Cansaran, 2014).

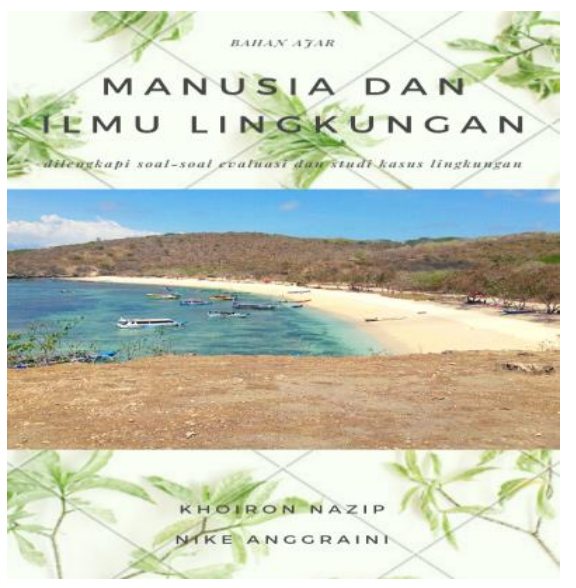

Gambar 1. Desain Produk Bahan Ajar

\section{- Studi Pendahuluan} lingkungan. a. Desain Produk dikembangkan.

\section{HASIL DAN PEMBAHASAN}

Tahapan ini bertujuan untuk menggali pengetahuan awal siswa tentang komponen literasi sains yang mencakup keterampilan, pengetahuan sains dalm hal ini ekologi, kognitif, afektif dan prilaku.dari hasil identifikasi awal, sebanyak $74 \%$ siswa menyebutkan bahwa kerusakan sungai dan rawa akibat penggalian tambang dan penimbunan rumah menjadi permasalahan yang paling banyak terjadi di Sumatera Selatan. Hal ini menjadi indikator bahwa sebagian besar siswa menyadari telah terjadinya kersakan lingkungan di daerah mereka. Dimana kerusakan yang terjadi berbeda dengan kondisi tiap daerah yang ada di Indonesia. Sedangkan, bahan ajar yang digunakan dalam perkuliahan ataupun disekolah merupakan buku ajar berstandar nasional yang seragam serta tidak mengandung unsur realitas lokal yang terjadi di daerah masing-masing.

Pengembangan bahan ajar ini bertujuan untuk membekali siswa agar memiliki kecakapan literasi sains yang mengacu pada karateristikkarateristik kunci oleh NAAEE (2004) tentang karateristik bahan ajar yang memuat literasi

\section{- Pengembangan Produk}

Pada tahapan ini telah didapatkan desainproduk dari bahan ajar yang akan

\section{DAFTAR ISI}

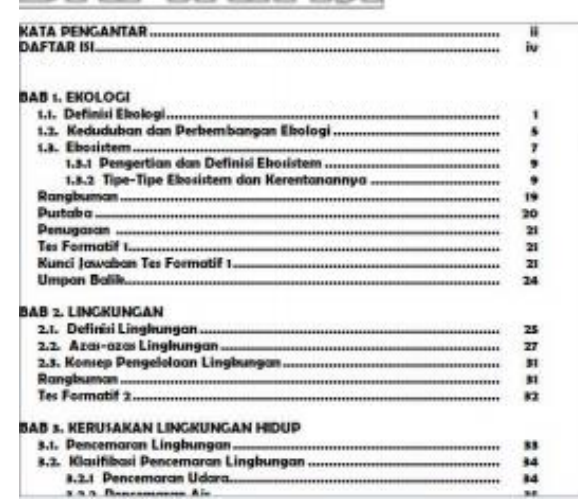

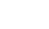




\section{b. Pengembangan Produk}

Pengembangan produk dalam bentuk prototipe yang selanjutnya di lakukan ui validasi oleh ahli materi, ahli teknologi dan uji keterbacaan

\section{- Hasil Validasi Ahli Materi dan Teknologi}

\section{a) Validasi oleh ahli}

Validasi yang dilakukan oleh ahli materi dan ahli teknologi bertujuan untuk mendapatkan uji kelayakan terhadap bahan ajar yang dikembangkan apakah telah sesuai dengan standar BSNP. Hasil validasri berupa data kualitatif yang berupa penilaian, pendapat serta saran dari ahli materi.

Hasil tanggapan dan hasil uji coba dengan sampel besar dijadikan acuan dalam memperbaiki draft bahan ajar, penyempurnaan terus dilakukan hingga terwujudnya bahan ajar perubahan lingkungan yang baik dan sesuai standar. Penilaian dari para ahli ditunjukkan dalam tabel 1.

Tabel 1. Hasil Validasi Bahan Ajar oleh ahli materi dan ahli teknologi.

\begin{tabular}{|c|c|c|c|c|}
\hline Penilaian ahli materi & Penilaian/skor & Item & $\begin{array}{l}\text { Skor } \\
\text { BSNP }\end{array}$ & Kategori \\
\hline \multicolumn{5}{|l|}{ Aspek Kelayakan Isi } \\
\hline Kesesuaian materi dengan KI dan KD & 9.21 & 4 & 3.11 & \\
\hline Keakuratan materi. & 20.54 & 8 & 3.19 & \\
\hline Kemutakhiran materi. & 12.34 & 4 & 2.92 & \\
\hline Mendorong keingintahuan & 6.00 & 4 & 3.00 & \\
\hline \multicolumn{5}{|l|}{ Aspek Kelayakan Penyajian. } \\
\hline Teknik penyajian & 6.00 & 3 & 3.00 & \\
\hline Pendukung penyajian & 22.00 & 6 & 3.00 & \\
\hline Penyajian pembelajaran & 3.75 & 7 & 3.00 & \\
\hline Koherensi dan keruntutan alur pikir & 6.78 & 4 & 2.83 & \\
\hline \multicolumn{5}{|l|}{ Aspek Kontekstual } \\
\hline Hakikat kontekstual & 7.88 & 3 & 3.67 & \\
\hline Komponen kontekstual & 23.45 & 7 & 3.44 & \\
\hline Rata-Rata & & & 3.05 & \\
\hline Jumlah skor yang diperoleh & 117.95 & & & Layak \\
\hline Jumlah Skor Maksimum & 143 & & & \\
\hline Persentase skor yang diperoleh & $82,4 \%$ & & & \\
\hline \multicolumn{5}{|l|}{ Penilaian Ahli Teknologi } \\
\hline \multicolumn{5}{|l|}{ Aspek Kelayakan Isi } \\
\hline Ukuran bahan ajar & 7.50 & 4 & 3.00 & \\
\hline Desain sampul bahan ajar & 21.54 & 5 & 3.05 & \\
\hline Desain bahan ajar & 28.90 & 8 & 2.97 & \\
\hline \multicolumn{5}{|l|}{ Aspek Kelayakan Bahasa } \\
\hline Lugas & 9.89 & 2 & 3.22 & \\
\hline Komunikatif & 3.33 & 3 & 3.33 & \\
\hline Dialogis dan interaktif & 6.17 & 2 & 3.17 & \\
\hline Sesuai dengan perkembangan siswa & 5.33 & 2 & 2.67 & \\
\hline Sesuai dengan kaidah bahasa & 6.78 & 2 & 2.83 & \\
\hline Penggunaan istilah dan simbol/ikon & 7.01 & 2 & 2.83 & \\
\hline Rata-Rata & & & 3.00 & \multirow{4}{*}{ Layak } \\
\hline Jumlah skor yang diperoleh & 96,45 & & & \\
\hline Jumlah Skor Maksimum & 123 & & & \\
\hline Persentase skor yang diperoleh & $78,4 \%$ & & & \\
\hline
\end{tabular}

Berdasarkan data hasil penilaian ahli materi dan ahli teknologi pembelajaran, diperoleh hasil penilaian seperti tertuang dalam Tabel 1. Ratarata hasil penilaian dari ahli materi 3.05 untuk kelayakan isi dan rata-rata yang diperoleh dari ahli teknologi 3.00 untuk kelayakan kegrafikaan. Sesuai dengan standar yang digunakan oleh BSNP, dapat disimpulkan bahwa bahan ajar perubahan ligkungan layak untuk diujicobakan. 


\section{b) Hasil Uji Keterbacaan}

Bahan ajar yang telah dinilai oleh validator, selanjutnya dilakukan revisi sesuai masukan dan saran yang diberikan. Selanjutnya dilakukan uji keterbacaan dalam skala terbatas dan pada skala yang lebih luas. Tingkat keterbacaan bahan ajar yang telah dikembangkan, diukur melalui uji keterbacaan dengan uji rumpang (cloze test). Jumlah bagian disesuaikan dengan jumlah Bab yang ada pada bahan ajar. Analisis hasil uji rumpang sampel kecil disajikan pada tabel 2 .

Tabel 2. Hasil cloze test pada uji keterbacaan pada skala kecil

\begin{tabular}{|c|c|c|c|}
\hline Bagian & $\begin{array}{c}\text { \% rata-rata } \\
\text { tingkat } \\
\text { keterbacaan }\end{array}$ & Kategori & $\begin{array}{c}\text { Keteran } \\
\text { gan }\end{array}$ \\
\hline Bagian 1 & 83.50 & Tinggi & \multirow{6}{*}{$\begin{array}{l}\text { Tidak } \\
\text { perlu } \\
\text { Revisi }\end{array}$} \\
\hline Bagian 2 & 82.34 & Tinggi & \\
\hline Bagian 3 & 81.98 & Tinggi & \\
\hline Bagian 4 & 83.20 & Tinggi & \\
\hline Bagian 5 & 86,45 & Tinggi & \\
\hline Rata-Rata & 83.49 & Tinggi & \\
\hline
\end{tabular}

Rangkuman analisis hasil uji rumpang sampel kecil pada Tabel 2 terlihat bahwa rata-rata tingkat keterbacaan masing-masing bagian dalam kategori tinggi sesuai dengan kategori tingkat keterbacaan menurut (Ozgurler \& Cansaran, 2014). Dimana kategori tingkat keterbacaan bahan ajar tinggi apabila TK > 57\%, sedang: $44 \%$ TK < 57\%, dan rendah: TK < 44\% (Ozgurler \& Cansaran, 2014). Tingkat keterbacaan yang tinggi dari analisis hasil uji rumpang sampel kecil menunjukkan bahwa draft bahan ajar perubahan lingkungan yang dikembangkan layak untuk diujicobakan pada sampel besar. Analisis Uji Keterbcaan dengan sampel besar yang berjumlah 75 orang disajikan pada tabel 3 berikut.

Tabel 3. Hasil cloze test pada uji keterbacaan dengan skala besar

\begin{tabular}{lccl}
\hline Bagian & $\begin{array}{l}\text { \% rata-rata } \\
\text { tingkat } \\
\text { keterbacaan }\end{array}$ & $\begin{array}{l}\text { Katego } \\
\text { ri }\end{array}$ & $\begin{array}{l}\text { Ketera } \\
\text { ngan }\end{array}$ \\
\cline { 1 - 3 } Bagian 1 & 84.57 & Tinggi & Tidak \\
\cline { 1 - 3 } Bagian 2 & 83,96 & Tinggi & perlu \\
\cline { 1 - 3 } Bagian 3 & 84.56 & Tinggi & Revisi \\
\cline { 1 - 3 } Bagian 4 & 83.90 & Tinggi & \\
\cline { 1 - 3 } Bagian 5 & 88.91 & Tinggi & \\
\cline { 1 - 3 } Rata-Rata & $\mathbf{8 5 . 1 8}$ & Tinggi & \\
\hline
\end{tabular}

Berdasarkan data di tabel 3, terjadi kenaikan untuk skor pada masing-masing bab dalam bahan ajar. Hal ini disebabkan karena dalam uji coba skala besar, telah dilakukan banyak perbaikan berdasarkan para ahli dan melihat kekurangan pada ujicoba skala kecil sebelumnya. Adapun perbandingan persentase tingkat keterbacan untuk tiap kelas Palembang dan Indralaya disajikan pada Gambar 2.

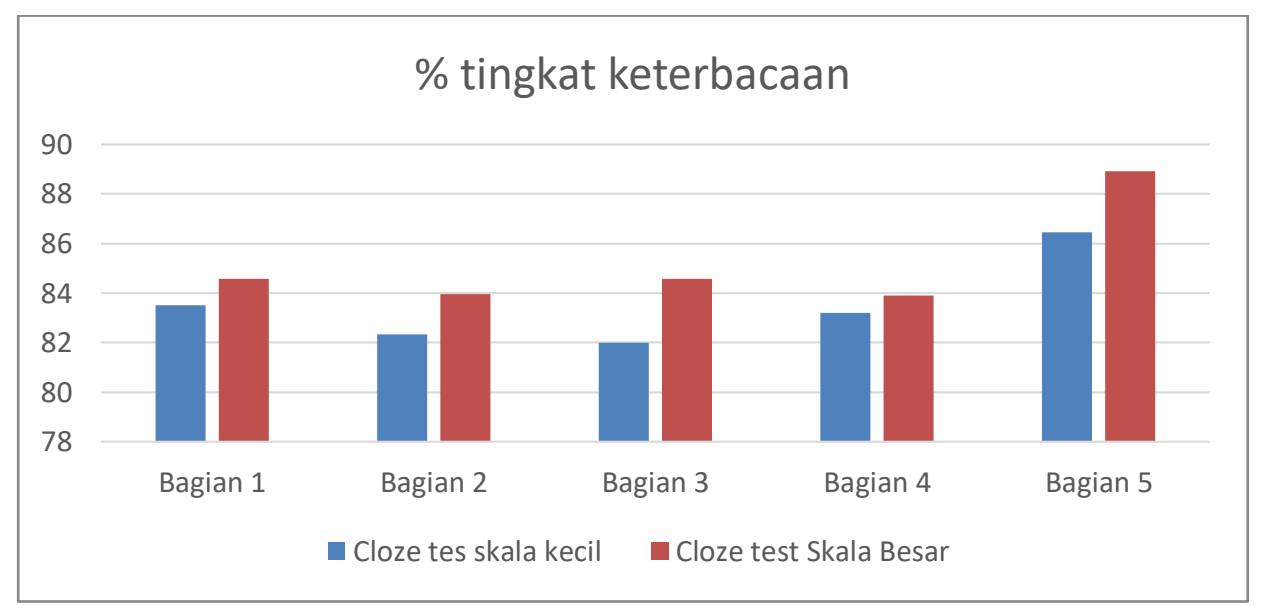

Gambar 2. Perbandingan tingkat keterbacaan pada uji coba cloze test untuk skala kecil dan skala besar

Berdasarkan persentase yang didapat, atas $70 \%$ untuk setiap bagian pada bahan ajar. menunjukkan bahwa uji keterbacaan siswa di Merujuk pada konversi untuk kategori tingkat 
keterbacaan tingkat keterbacaan di atas 70\% berada dalam kategori tinggi. Hal tersebut sesuai dengan pernyataan (HM. Taufiqi, 2016), bahwa masa terbaik dimana penanaman karakter dilakukan yakni masa anak usia dini. Jika masa ini terlewatkan maka akan semakin sulit membentuk karakter yang baik, terutama sikap cinta lingkungan (Hanna \& Rini, 2015), mengatakan bahwa pembelajaran yang dapat memotivasi siswa lebih mengenal lingkungan dapat meningkatkan pengetahuan siswa tentang lingkungan hidup.

\section{KESIMPULAN}

Bahan ajar berorientasi Environmental Sustainablity Education berbasis Literasi sains dan Realitas Lokal telah berhasil dikembangkan melalui tahapan yang ada. Kualitas bahan ajar berdasarkan penilaian dari ahli materi dalam kategori layak diuji cobakan dengan rata-rata skor komposit 3.05, penilaian ahli teknologi dalam kategori layak dengan rata-rata skor komposit 3.00. Bahan ajar ini telah layak untuk digunakan pada proses pembelajaran di Pendidikan Biologi FKIP Unsri.

\section{DAFTAR PUSTAKA}

Abu-Hola, I. (2011). An Islamic Perspective on Environmental Literacy. Education.

Azhar, A., Basyir, M. D., \& Alfitri, A. (2016). Hubungan Pengetahuan Dan Etika Lingkungan Dengan Sikap Dan Perilaku Menjaga Kelestarian Lingkungan. Jurnal Ilmu Lingkungan.

https://doi.org/10.14710/jil.13.1.36-41

Badan Pusat Statistik. (2013). Statistik Indonesia 2013. Katalog BPS.

Chiras, D. D. (1991). Environmental science: Action for a sustainable future (3rd ed.). Benjamin/Cummings Pub. Co; 3rd edition.

Cunningham, D. (2008). Literacy Environment Quality in Preschool and Children's Attitudes toward Reading and Writing. Literacy Teaching and Learning, 12(2), 19-36.
Hanna, S \& Rini, R., S. (2015). Pembuatan Video Pembelajaran Lingkungan Hidup Berbasis Kondisi Lokal Untuk Meningkatkan Pengetahuan dan Sikap. Gadjah Mada. Retrieved from http://etd.repository.ugm.ac.id/home/detail_pe ncarian/81351

HM. Taufiqi. (2016). Religious Parenting Hypnoteaching and Hypnotherapy for Brilliant Kids. Malang: Media Sutra Atiga.

Jack R. Fraenkel, Norman E. Wallen, H. H. H. (2012). How to Desigen and Evaluate Reserch in Education (8rd ed.). NEW YORK.

National Asociation for Environmental Education (NAEE) . (2011). Environmental Literacy Framework. Retrieved from https://naaee.org/our-

work/programs/environmental-literacyframework

Ozgurler, S., \& Cansaran, A. (2014). Graduate Students, Study of Environmental Literacy and Sustainable Development. International Electronic Journal of Environmental Education, $\quad 4(2), \quad 71-83$. https://doi.org/10.18497/iejee-green.31036

PISA. (2016). PISA 2015 Results in Focus. $O E C D$.

Segara, N. B. (2015). Education For Sustainable Development (Esd) Sebuah Upaya Mewujudkan Kelestarian Lingkungan. Sosio Didaktika: Social Science Education Journal, 2(1), 22-30. https://doi.org/10.15408/sd.v2i1.1349

Sontay, G., Gökdere, M., \& Usta, E. (2015). A comparative investigation of sub-components of the environmental literacy at the secondary school level. Journal of Turkish Science Education.

https://doi.org/10.12973/tused.10130a

Sriyati, S. (2015). Pengembangan Bahan Ajar Perubahan Lingkungan Berbasis Realitas Lokal dan Literasi Lingkungan. Jurnal Pendidikan Biologi, 12, 151-161.

Steg, L., Dreijerink, L., \& Abrahamse, W. (2005). Factors influencing the acceptability of energy policies: A test of VBN theory. Journal of Environmental Psychology. https://doi.org/10.1016/j.jenvp.2005.08.003 